\title{
Organogenesis and plant selection by kanamycin of strawberry in vitro aiming at genetic transformation
}

\section{Organogênese e seleção por canamicina de plantas de morangueiro in vitro visando a transformação genética}

\author{
Letícia Reis $^{1^{*}}$; Ricardo Antônio Ayub ${ }^{2}$
}

\begin{abstract}
The success of genetic transformation of the strawberry (Fragaria x ananassa) is strongly influenced by the cultivar and depends on efficient regeneration and plant-transformed selection. In plant regeneration, efficient organogenesis depends on the concentrations of plant growth regulators that are present in the culture medium, and the response varies according to the explant type and cultivar. Similarly, in the selection of transformed plants, the sensitivity to selective agents induced by marker genes depends on the concentration of the selective substance in the regeneration medium and must be adjusted according to the chosen cultivar. The aim of this work was to test different combinations and concentrations of TDZ (Thidiazuron) and IBA (indolebutyric-acid) added to the base medium MS (MURASHIGE; SKOOG, 1962) for shoot regeneration of Camiño Real and Festival cultivars from leaf and petiole explants. In the case of 'Camiño Real', 1.0, 1.5 and $2.0 \mathrm{mg} \mathrm{L}^{-1}$ of TDZ combined with $0.1,0.3$ and $0.5 \mathrm{mg} \mathrm{L}^{-1}$ of IBA were tested. In the case of 'Festival', 1.0, 1.5 and $2.0 \mathrm{mg} \mathrm{L}^{-1}$ of TDZ combined with 0.1 and $0.3 \mathrm{mg} \mathrm{L}^{-1}$ of IBA were evaluated. Another aim was to define the lowest concentration of the selective agent Kanamycin (marker gene $n p t I I$ ) able to inhibit regeneration of the untransformed shoots. For this purpose, Kanamycin doses of $0,2,4,6,8$ and $10 \mathrm{mg} \mathrm{L}^{-1}$ were added to the pre-established regeneration medium. In the petiole explant test, normal shoot regeneration did not occur; thus, only shoot regeneration and the sensitivity to Kanamycin from leaf explants were analyzed. For 'Camiño Real' the best shoot regeneration was established with a combination of $2.0 \mathrm{mg} \mathrm{L}^{-1}$ of TDZ $+0.1 \mathrm{mg} \mathrm{L}^{-1}$ of IBA. On the other hand, for 'Festival' the best shoot regeneration was established with a combination of $2.5 \mathrm{mg} \mathrm{L}^{-1}$ of TDZ $+0.1 \mathrm{mg} \mathrm{L}^{-1}$ of IBA. As far as Kanamycin sensitivity is concerned, total inhibition of the shoots was observed with $10 \mathrm{mg} \mathrm{L}^{-1}$ with both cultivars.
\end{abstract}

Key words: Tissue culture, antibiotics, Fragaria $x$ ananassa

\section{Resumo}

O sucesso da transformação genética do morangueiro (Fragaria x ananassa) é grandemente influenciado pela cultivar utilizada e dependente da eficiente regeneração e seleção do material transformado. Na regeneração das plantas, a organogênese depende da concentração de reguladores de crescimento presente no meio de cultivo e varia de acordo com a fonte de explante e a cultivar utilizada. Da mesma forma, na seleção das plantas transformadas, a sensibilidade à agentes seletivos induzida por genes marcadores, depende da concentração da substância seletiva no meio de regeneração e deve ser ajustada de acordo com a cultivar utilizada. O objetivo deste trabalho foi testar diferentes combinações e concentrações de TDZ (Thidiazuron) e AIB (Ácido Indolbutírico) adicionados ao meio básico MS

\footnotetext{
1 Discente do curso de Doutorado, Programa de Pós-Graduação em Agronomia, Universidade Estadual de Ponta Grossa, UEPG, Ponta Grossa, PR, Brasil. E-mail: lereis04@hotmail.com

2 Prof. Dr., Dept ${ }^{\circ}$ de Fitotecnia e Fitossanidade, Universidade Estadual de Ponta Grossa, UEPG, Ponta Grossa, PR. Brasil. E-mail: rayub@uepg.br

* Author for correspondence
} 
(MURASHIGE; SKOOG, 1962) para a regeneração de brotos das cvs. Camiño Real e Festival a partir de explantes foliares e explantes peciolares. Para a cv. Camiño Real foram testados 1,0; 1,5 e 2,0 mg $\mathrm{L}^{-1}$ de TDZ combinadas com 0,$1 ; 0,3$ e $0,5 \mathrm{mg} \mathrm{L}^{-1}$ de AIB e para a cv. Festival foram testados 1,$0 ; 1,5$ e 2,0 $\mathrm{mg} \mathrm{L}^{-1}$ de TDZ combinados com 0,1 e $0,3 \mathrm{mg} \mathrm{L}^{-1}$ de AIB. A partir dos resultados de regeneração, também se buscou definir a menor concentração do agente seletivo canamicina (gene marcador $n p t$ II), capaz de inibir a regeneração de brotos não transformados, testando-se adições de $0,2,4,6,8$ e $10 \mathrm{mg} \mathrm{L}^{-1}$ de canamicina ao meio de regeneração pré-estabelecido. Para ambas as cultivares não foram obtidos brotos com desenvolvimento normal a partir de explantes peciolares, sendo avaliadas apenas a regeneração e sensibilidade à canamicina de brotos regenerados a partir de explantes foliares. Para a cv. Camiño Real foi estabelecida a melhor regeneração de brotos na combinação $2,0 \mathrm{mg} \mathrm{L}^{-1}$ de TDZ + $0,1 \mathrm{mg} \mathrm{L}^{-1}$ de AIB enquanto que para a cv. Festival foram $2,5 \mathrm{mg} \mathrm{L}^{-1}$ de TDZ $+0,1 \mathrm{mg} \mathrm{L}^{-1}$ de AIB. Com relação a sensibilidade à canamicina, foi observada total inibição de brotos com $10 \mathrm{mg} \mathrm{L}^{-1}$ de canamicina para ambas as cultivares estudadas.

Palavras-chave: Cultura de tecidos, antibióticos, Fragaria $x$ ananassa

\section{Introdution}

The strawberry (Fragaria $x$ ananassa L. Duch) is an octaploid $(2 \mathrm{n}=8 \mathrm{x}=56)$, non-climateric fruit highly appreciated for its flavor and nutritive quality (SONG et al., 2009). However, it suffers a loss of firmness during ripening, reflected in reduced shelf life, which affects its commercialization (BAPAT et al., 2010). Thus, genetic engineering studies have been done to improve fruit firmness; for instance, the suppression of cell wall degrading enzymes like pectate lyases (JIMÉNEZ-BERMÚDEZ et al., 2002), endo- $\beta$ - $(1,4)$-glucanases (PALOMER et al., 2006) and poligalacturonases - FaPG1 and FaPG2 (QUESADA et al., 2009). Additionally, studies directly related to understanding fruit ripening, associated with the role of ethylene, have also been extensively explored (SUN et al., 2013; VILLARREAL et al., 2010; TRAINOTTI et al., 2005).

When it comes to an octaploid hybrid plant, strawberry genetic breeding by traditional methods is inefficient, takes a long time and requires a major workforce. However, biotechnology and genetic engineering techniques are being extensively used in strawberry breeding and to increase the availability of germoplasm (QIN et al., 2008). Among these techniques, genetic transformation by Agrobacterium tumefaciens is a standard and efficient method applied to strawberry breeding (DEBNATH; TEIXEIRA DA SILVA, 2007); nonetheless, this depends not only on the use of an appropriate transformation protocol, but also on the prior establishment of an efficient system to recover and identify transformed plants (QIN et al., 2011).

Based on plant cell totipotency (BISWAS et al., 2010), organogenesis consists of organ differentiation from tissue fragments due to combinations of types and levels of auxin and cytokinin in the culture medium (HUSAINI et al., 2011; MOTTE et al., 2013), in addition to the cell division and cell expansion capabilities performed by these plant growth regulators (GASPAR et al., 2003). However, the organogenesis response varies with the source of the cultivar, explant type and concentration of plant growth regulators in the regeneration medium (ZAKARIA et al., 2013; HUSAINI et al., 2011).

According to Haddadi et al. (2010), in strawberry regeneration medium, the citokinin must be at a higher concentration than the auxin, because they play a major role in shoot multiplication. Among citokinins frequently used in strawberry regeneration, 6-benzilamino-purine (BA) and tidiazuron (TDZ) have been recently used. These may be used alone or in combination with an auxin such as indolebutyric acid (IBA) (LANDI; MEZZETTI, 2006) to improve the regeneration rate and number of shoots per explant (MURTIL et al., 2012). 
In organogenesis, another important factor is the type of explant. In strawberry shoot regeneration many types of explants are known, such as sepals, callus and somatic embryos; however, in particular, leaves and petioles provide the highest rates of regeneration, although responses may differ according to the cultivar (HUSAINI et al., 2011).

Besides regeneration, identification and selection of the transformed plants is extremely important, because efficient genetic transformation depends on an efficient selection system (SILVA et al., 2010). Marker genes that induce resistance to substances such as antibiotics assist in transformed plant selection by inhibiting untransformed shoot growth (ABDAL-AZIZ et al., 2006; KARAMI et al., 2009; QIN et al., 2011). Many transformation methods use the nptII gene, which confers resistance to the aminoglycoside group of antibiotics (neomycin, kanamycin, and gentamicin), to transform cells (MARCELLINO et al., 2007; QIN et al., 2011; PANTAZIS et al., 2013). However, the selective agents can have a negative effect on callus induction and regeneration capacity and vary according to the concentration, species, cultivar and explant type (KARAMI et al., 2009).

In this context, we emphasize the importance of preset plant regeneration and plant selection protocols according to the cultivar and the explant type. Thus, the aim was to evaluate organogenesis of the 'Camiño Real' and 'Festival' strawberry cultivars from leaf and petiole explants submitted to different concentrations and combinations of TDZ and IBA. Furthermore, we evaluated kanamycin antibiotic sensibility, increasing concentrations in the preset regeneration medium in order to establish the lowest concentration able to inhibit the regeneration of untransformed plants.

\section{Materials and Methods}

\section{Experiment I}

Seedlings of 'Camiño Real' and 'Festival' strawberry were cultured in vitro by fresh achenes germination in MS medium (MURASHIGE; SKOOG, 1962) with half salt concentration. Afterward, these seedlings were segmented into leaf explants of approximately $1 \mathrm{~cm}^{2}$ and petiole explants approximately $1 \mathrm{~cm}$ in length. They were submitted to organogenesis in different regeneration media composed of the base medium MS (MURASHIGE; SKOOG, 1962) and supplemented with different combinations of the plant growth regulators Thidiazuron (TDZ) and Indolebutyric-acid (IBA).

For 'Camiño Real', 1.0, 1.5 and $2.0 \mathrm{mg} \mathrm{L}^{-1}$ of TDZ, combined with $0.1,0.3$ and $0.5 \mathrm{mg} \mathrm{L}^{-1}$ of IBA, were tested, corresponding to nine treatments, conducted in a completely randomized design in a $3 \times 3$ factorial arrangement. On the other hand, for 'Festival', 2.0, 2.5 and $3.0 \mathrm{mg} \mathrm{L}^{-1}$ of TDZ combined with 0.1 and $0.3 \mathrm{mg} \mathrm{L}^{-1}$ of IBA were evaluated, corresponding to six treatments, conducted in a completely randomized design in a $3 \times 2$ factorial arrangement. For both cultivars, each treatment was composed of five repetitions (petri dishes), and these consisted of six explants each.

The Petri dishes with the different regeneration media were placed in a growth room at $25 \pm 2{ }^{\circ} \mathrm{C}$ with a photoperiod of 16 hours and luminous intensity of $2000 \mu \mathrm{M} \mathrm{m}^{-2} \mathrm{~s}^{-1}$. After 45 days, the numbers of buds and shoots per explant were evaluated. The data was submitted to statistical analysis of variance (ANOVA) and the means were compared by Tukey's test at a $5 \%$ error probability $(\mathrm{p} \leq 0.05)$ using the ASSISTAT statistical program (SILVA; AZEVEDO, 2009).

\section{Experiment II}

Based on the experiment I results, Kanamycin growth doses were added $(0,2,4,6,8$ and $10 \mathrm{mg}$ $\left.\mathrm{L}^{-1}\right)$ to the best regeneration medium in order to define the lowest concentration able to inhibit the regeneration of untransformed plants. For 'Camiño Real', the best regeneration medium was composed of MS basic medium $+2.0 \mathrm{mg} \mathrm{L}^{-1}$ of TDZ +0.1 $\mathrm{mg} \mathrm{L^{-1 }}$ of IBA, whereas, for 'Festival', the best 
regeneration medium was composed of MS base medium $+2.5 \mathrm{mg} \mathrm{L}^{-1}$ of TDZ $+0.1 \mathrm{mg} \mathrm{L}^{-1}$ of IBA.

The experimental implementation methodology followed the one described for experiment I. Experiment II was evaluated in a completely randomized design in a one-factor arrangement. After 45 days the numbers of buds and shoots per explant were evaluated. The data was submitted to statistical analysis of variance (ANOVA) and the means were compared by Tukey's test at a 5\% error probability ( $\mathrm{p} \leq 0.05)$ with the ASSISTAT statistical program (SILVA; AZEVEDO, 2009).

\section{Results and Discussion}

\section{Experiment I}

The use of petiole explants for shoot regeneration in both cultivars was not efficient and could not be statistically evaluated. With petiole explants the regeneration culture media analyzed induced only a small number of abnormal shoots, showing twisted and deformed leaves, without petiole training and with a greenish to reddish color (Figure 1A). Furthermore, there was no bud formation, but only callus formation in the cutting explant area, also in small quantities (Figure 1B).

Figure 1. Strawberry petiole explants with abnormal shoot formation, showing undefined leaf and petiole forms (A) small quantities of callus formation and only on the cutting region - set indicated (B). Leaf explant regeneration of whole shoots, able to regenerate new viable strawberry plants (C).

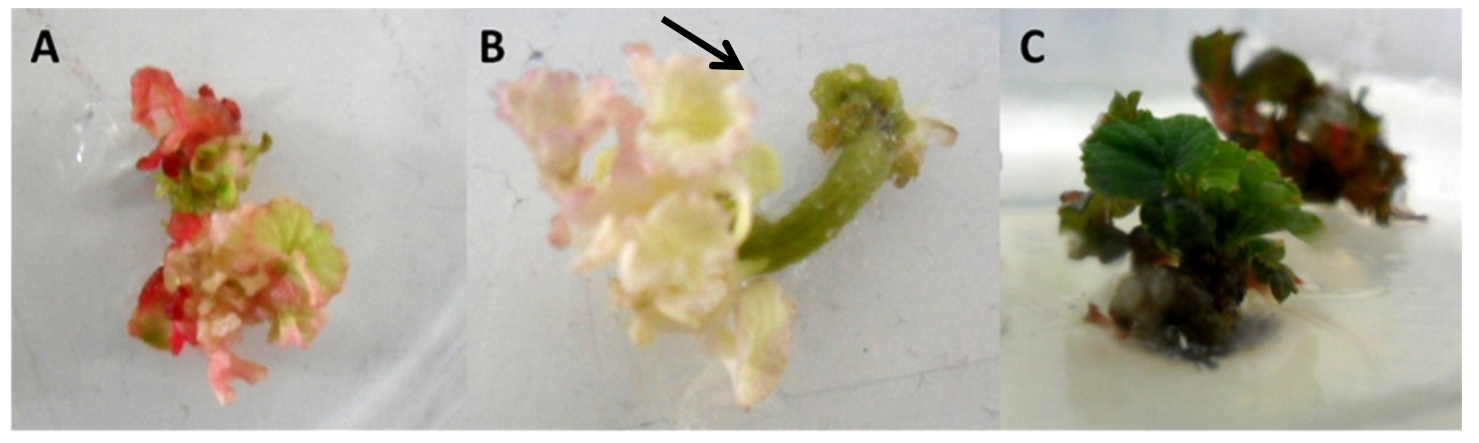

The action of TDZ on callus growth in woody species has been observed in many species and this regulator is considered an excellent callus inducer (HUETTEMAN; PREECE, 1993); however, the callus induction in strawberry, which is not a woody species, is an interesting result and is probably associated with the presence of IBA. However, despite TDZ's morphological efficiency for morphogenesis, it may also have adverse results, such as explant oxidation by induction of ethylene biosynthesis (CARVALHO et al., 2011). This suggests the use of other cytokines to promote organogenesis in strawberry petiole explants.

On the other hand, with leaf explants we observed viable shoot development for both cultivars, showing a plant completely capable of regenerating in vitro (Figure 1C). According to Husaini et al. (2011), although most strawberry regeneration studies describe the use of leaf and petiole explants, is well known that the leaf tissue has better regenerative capacity than other tissues, so that the rates of regeneration of shoots using this type of explant are generally high, although very cultivar dependent.

To evaluate the combination of plant growth regulators it is important to note that there was no significant interaction between the TDZ and IBA concentrations and, therefore, the mean comparison was done considering the treatments as unifactorial. For 'Camino Real', using leaf explants, the largest number of shoots was obtained with the T5 treatment (1.5 mg L-1 $\left.\mathrm{TDZ}+0.3 \mathrm{mg} \mathrm{L}^{-1} \mathrm{IBA}\right)$, 
with an average of 3.19 buds per explant; however, only the T9 treatment differed significantly $(2.0 \mathrm{mg}$ $\left.\mathrm{L}^{-1}+\mathrm{TDZ} 0.5 \mathrm{mg} \mathrm{L}^{-1} \mathrm{IBA}\right)$. As for the number of shoots, the $\mathrm{T} 7$ treatment $\left(2.0 \mathrm{mg} \mathrm{L-}{ }^{1} \mathrm{TDZ}+0.1 \mathrm{mg}\right.$ $\mathrm{L}^{-1}$ IBA) showed the best result, around 2.3 shoots per explant (Table 1).
On the other hand, with 'Festival', the largest number of shoots was obtained in treatments $\mathrm{T} 1$ (2.0 $\left.\mathrm{mg} \mathrm{L}^{-1} \mathrm{TDZ}+0.1 \mathrm{mg} \mathrm{L}^{-1} \mathrm{IBA}\right)$ and $\mathrm{T} 2(2.0 \mathrm{mg}$ $\mathrm{L}^{-1} \mathrm{TDZ}+0.3 \mathrm{mg} \mathrm{L}^{-1} \mathrm{IBA}$ ), averaging 5.7 and 4.6 buds per explant, respectively. The largest number of shoots per explant was obtained with treatments T3 (2.5 mg L-1 TDZ + $\left.0.1 \mathrm{mg} \mathrm{L}^{-1} \mathrm{IBA}\right)$ and T4 (2.5 $\mathrm{mg} \mathrm{L}^{-1} \mathrm{TDZ}+0.3 \mathrm{mg} \mathrm{L}^{-1}$ IBA), with 2.06 and 1.6 shoots per explant, respectively (Table 2 ).

Table 1. Number of buds and shoots obtained by leaf explant organogenesis from 'Camiño Real' strawberry submitted to different combinations of Thidiazuron (TDZ) indolebutyric acid (IBA) after 45 days of culture.

\begin{tabular}{cccc}
\hline Treatment & Combination & Buds & Shoots \\
\hline $\mathrm{T} 1$ & $1.0 \mathrm{mg} \mathrm{L}^{-1} \mathrm{TDZ}+0.1 \mathrm{mg} \mathrm{L}^{-1} \mathrm{AIB}$ & $2.42 \mathrm{AB}$ & $0.71 \mathrm{BC}$ \\
$\mathrm{T} 2$ & $1.0 \mathrm{mg} \mathrm{L}^{-1} \mathrm{TDZ}+0.3 \mathrm{mg} \mathrm{L}^{-1} \mathrm{AIB}$ & $2.31 \mathrm{AB}$ & $1.16 \mathrm{AB}$ \\
$\mathrm{T} 3$ & $1.0 \mathrm{mg} \mathrm{L}^{-1} \mathrm{TDZ}+0.5 \mathrm{mg} \mathrm{L}^{-1} \mathrm{AIB}$ & $2.35 \mathrm{AB}$ & $0.75 \mathrm{BC}$ \\
$\mathrm{T} 4$ & $1.5 \mathrm{mg} \mathrm{L}^{-1} \mathrm{TDZ}+0.1 \mathrm{mg} \mathrm{L}^{-1} \mathrm{AIB}$ & $2.27 \mathrm{AB}$ & $1.46 \mathrm{AB}$ \\
$\mathrm{T} 5$ & $1.5 \mathrm{mg} \mathrm{L}^{-1} \mathrm{TDZ}+0.3 \mathrm{mg} \mathrm{L}^{-1} \mathrm{AIB}$ & $3.19 \mathrm{~A}$ & $1.41 \mathrm{AB}$ \\
$\mathrm{T} 6$ & $1.5 \mathrm{mg} \mathrm{L}^{-1} \mathrm{TDZ}+0.5 \mathrm{mg} \mathrm{L}^{-1} \mathrm{AIB}$ & $1.92 \mathrm{AB}$ & $1.04 \mathrm{BC}$ \\
$\mathrm{T} 7$ & $2.0 \mathrm{mg} \mathrm{L}^{-1} \mathrm{TDZ}+0.1 \mathrm{mg} \mathrm{L}^{-1} \mathrm{AIB}$ & $2.44 \mathrm{AB}$ & $2.29 \mathrm{~A}$ \\
$\mathrm{~T} 8$ & $2.0 \mathrm{mg} \mathrm{L}^{-1} \mathrm{TDZ}+0.3 \mathrm{mg} \mathrm{L}^{-1} \mathrm{AIB}$ & $2.44 \mathrm{AB}$ & $1.17 \mathrm{AB}$ \\
$\mathrm{T} 9$ & $2.0 \mathrm{mg} \mathrm{L}^{-1} \mathrm{TDZ}+0.5 \mathrm{mg} \mathrm{L}^{-1} \mathrm{AIB}$ & $0.92 \mathrm{~B}$ & $0.17 \mathrm{C}$ \\
\hline
\end{tabular}

Means followed by the same capital letter in the column do not differ statistically by Tukey test at $5 \%$ probability (p $\leq 0.05)$.

Table 2. Number of buds and shoots obtained by leaf explant organogenesis from 'Festival' strawberry submitted to different combinations of Thidiazuron (TDZ) indolebutyric acid (IBA) after 45 days of culture.

\begin{tabular}{cccc}
\hline Treatment & Combination & Buds & Shoots \\
\hline $\mathrm{T} 1$ & $2.0 \mathrm{mg} \mathrm{L}^{-1} \mathrm{TDZ}+0.1 \mathrm{mg} \mathrm{L}^{-1} \mathrm{AIB}$ & $5.66 \mathrm{~A}$ & $0.87 \mathrm{BC}$ \\
$\mathrm{T} 2$ & $2.0 \mathrm{mg} \mathrm{L}^{-1} \mathrm{TDZ}+0.3 \mathrm{mg} \mathrm{L}^{-1} \mathrm{AIB}$ & $4.60 \mathrm{AB}$ & $1.33 \mathrm{~B}$ \\
$\mathrm{~T} 3$ & $2.5 \mathrm{mg} \mathrm{L}^{-1} \mathrm{TDZ}+0.1 \mathrm{mg} \mathrm{L}^{-1} \mathrm{AIB}$ & $3.43 \mathrm{~B}$ & $2.06 \mathrm{~A}$ \\
$\mathrm{~T} 4$ & $2.5 \mathrm{mg} \mathrm{L}^{-1} \mathrm{TDZ}+0.3 \mathrm{mg} \mathrm{L}^{-1} \mathrm{AIB}$ & $1.73 \mathrm{BC}$ & $1.60 \mathrm{AB}$ \\
$\mathrm{T} 5$ & $3.0 \mathrm{mg} \mathrm{L}^{-1} \mathrm{TDZ}+0.1 \mathrm{mg} \mathrm{L}^{-1} \mathrm{AIB}$ & $1.43 \mathrm{C}$ & $0.21 \mathrm{C}$ \\
$\mathrm{T} 6$ & $3.0 \mathrm{mg} \mathrm{L}^{-1} \mathrm{TDZ}+0.3 \mathrm{mg} \mathrm{L}^{-1} \mathrm{AIB}$ & $1.81 \mathrm{BC}$ & $0.75 \mathrm{BC}$ \\
\hline \multicolumn{2}{c}{$\mathrm{CV}(\%)$} & 31.06 & 31.25 \\
\hline
\end{tabular}

Means followed by the same capital letter in the column do not differ statistically by Tukey's test at $5 \%$ probability $(\mathrm{p} \leq 0.05)$.

These results confirm that strawberry's organogenesis response varies according to the cultivar, explant type and concentration of plant growth regulators present in the regeneration medium, as described by Husaini et al. (2011), Haddadi et al. (2010) and Landi and Mezzetti (2006). In addition, for both cultivars, although the maximum number of shoots obtained was around 2 shoots per explant, 'Camino Real' achieved this result with a slightly lower concentration of TDZ than 'Festival', showing a fine line between optimal cytokinin levels for these cultivars. For 'Festival' it was also observed that when the TDZ concentration in the culture medium was increased 
to only $0.5 \mathrm{mg} \mathrm{L}^{-1}$, there was a significant reduction in bud formation, which, according to Haddadi et al. (2010), may be related to the high stability of TDZ in plant tissue. By increasing the concentration of endogenous cytokinin and inhibiting the action of cytokinin oxidase, it caused a reduction in the number of buds by having its regulator in excess in the tissue.

It was also observed that, for both cultivars, the IBA levels in the culture medium were very low, probably because TDZ is a synthetic substance with a similar action as cytokinins and auxins (MURTHY et al., 1998), apparently reducing the need for auxin in the regeneration medium. However, according to Murtil et al. (2012), the presence of auxins such as IBA seems to be an important factor in in vitro establishment of strawberry seedlings, significantly improving the development of shoots and roots and, therefore, they should not cease being used in addition to TDZ.

\section{Experiment II}

Adding increasing concentrations of Kanamycin antibiotic to the best 'Camino Real' and 'Festival' regeneration media, which had the highest shoot induction, we observed a differentresponse compared to those reported in the literature. In the strawberry, like regeneration, the antibiotic sensitivity response varies depending on the cultivar and explant type; however, their effects on morphogenesis, shoot growth and physiological changes have not been well reported (QIN et al., 2011). In strawberry (Fragaria $x$ ananassa L. Duch) the Kanamycin concentrations recommended are around $25 \mathrm{mg}$ $\mathrm{L}^{-1}$ for 'Toyonaka' (QIN et al., 2011) to $50 \mathrm{mg} \mathrm{L}^{-1}$ for 'Chandler' (HUSAINI, 2010). However, for 'Festival' and 'Camiño Real', preliminary studies (data not shown) at concentrations of $0,10,20,30$, 40 and $50 \mathrm{mg} \mathrm{L}^{-1}$ showed complete inhibition of callus, bud and shoot formation (Figure 2), making it impossible to establish a statistically meaningful inhibition curve at these concentrations.

Figure 2. Leaf explants of strawberry cultivar 'Camiño Real' submitted to increasing kanamycin concentrations $(0$, $10,20,30,40$ and $50 \mathrm{mg} \mathrm{L}^{-1}$ ) after 45 days of culture.

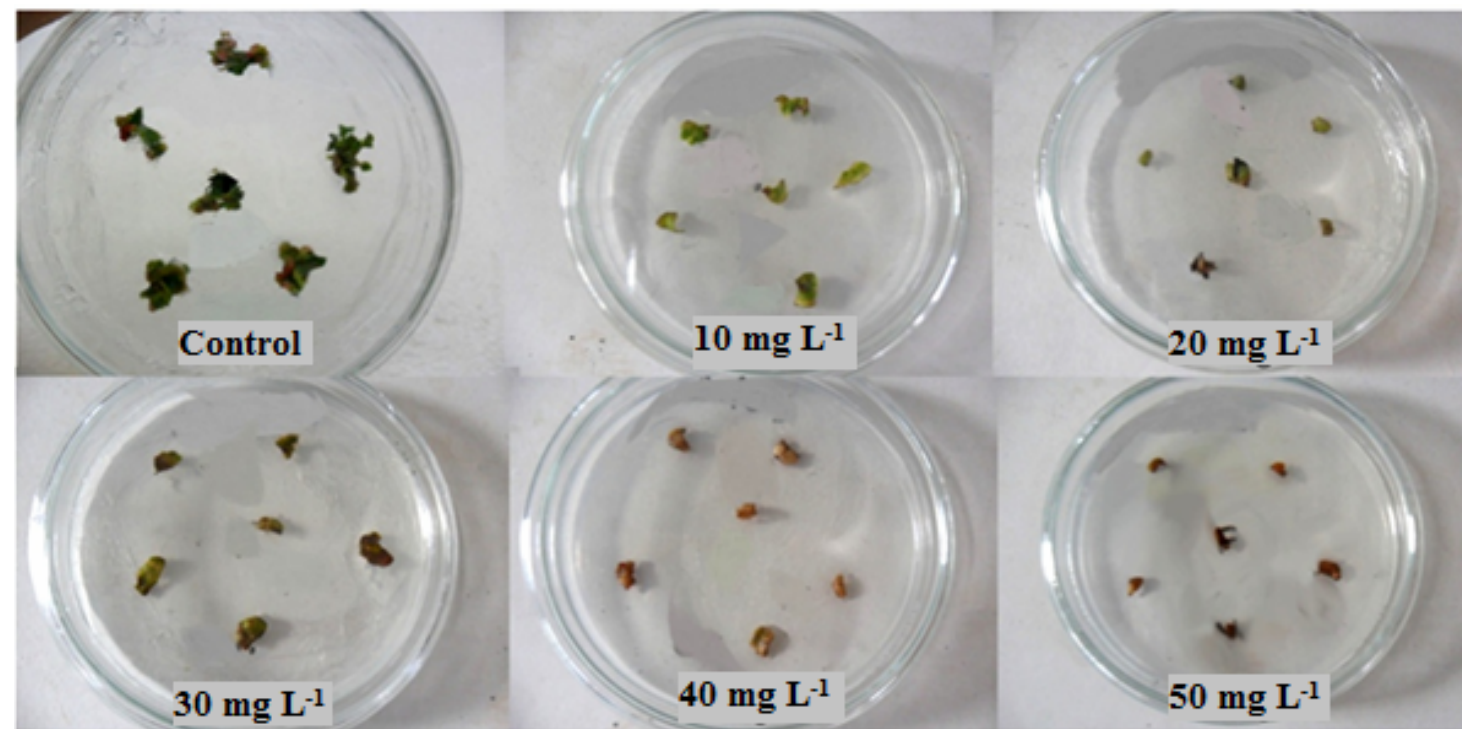


However, reducing the levels of kanamycin to $0, \quad$ inhibition at $10 \mathrm{mg} \mathrm{L}^{-1}$ for both varieties (Figure 2, 4, 6, 8 and $10 \mathrm{mg} \mathrm{L}^{-1}$ (this study), we observed 3 and Figure 4). In addition, we also observed an inhibition curve where increasing concentrations increased necrosis according to kanamycin dose, of kanamycin induced decreases in bud and shoot possibly due to electrolyte leakage and triggering formation, in accordance with Qin et al. (2011), of active enzymatic processes (PANTAZIS et al., culminating in complete callus, bud and shoot 2013).

Figure 3. Average of buds and shoots units per explant obtained from leaf explants of 'Camino Real' strawberry subjected to increasing concentrations of kanamycin antibiotic after 45 days of culture.

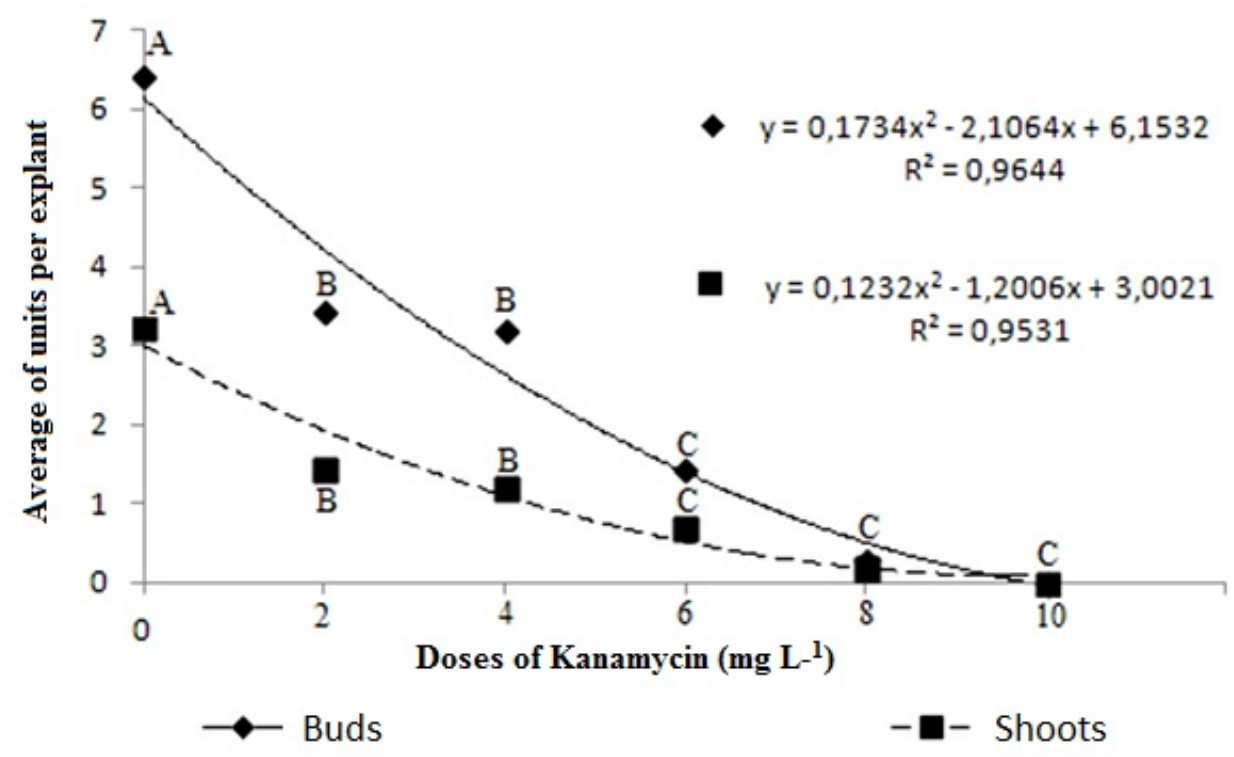

The same capital letter in the line do not differ statistically by Tukey test at $5 \%$ probability $(\mathrm{p} \leq 0.05)$.

Figure 4. Average of buds and shoots units per explant obtained from leaf explants of 'Festival' strawberry subjected to increasing concentrations of kanamycin antibiotic after 45 days of culture.

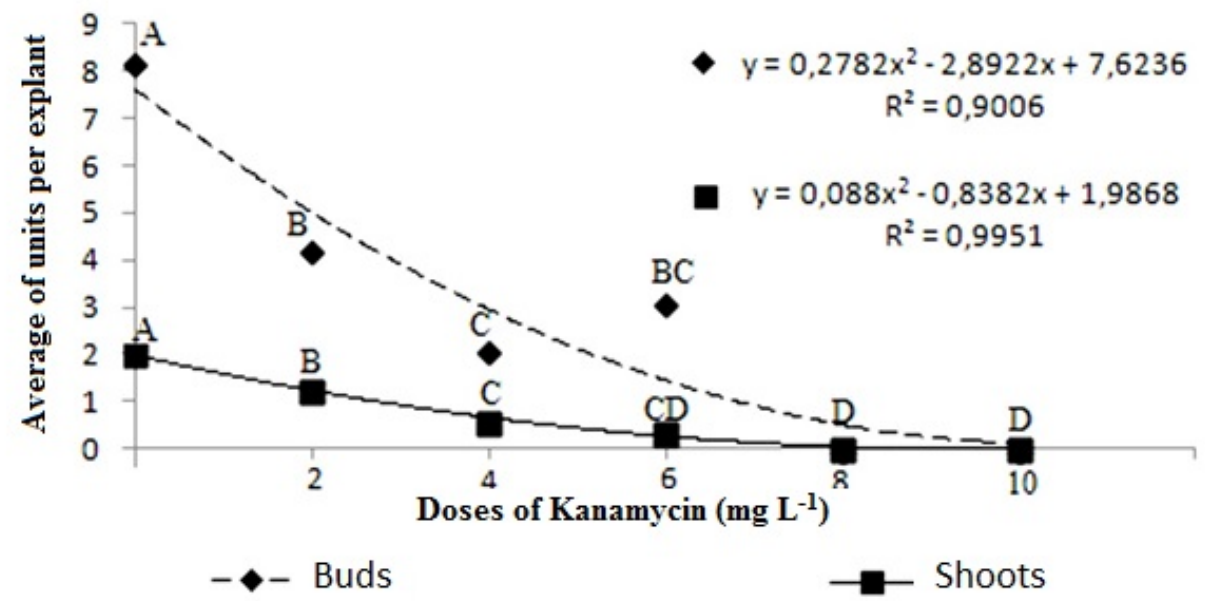

The same capital letter in the line do not differ statistically by Tukey test at $5 \%$ probability $(\mathrm{p} \leq 0.05)$. 
Although the production of callus, buds and shoots was followed by necrosis at lower concentrations of kanamycin (from $6 \mathrm{mg} \mathrm{L}^{-1}$ for 'Camiño Real' and $4 \mathrm{mg} \mathrm{L}^{-1}$ for 'Festival'), likewise inhibiting new plant regeneration, it is known that the selection of transformed plants for conferred resistance using marker genes can provoke the regeneration of untransformed shoots, for reasons still unknown (PANTAZIS et al., 2013). However, high concentrations can also affect the transformed plants' organogenesis, suggesting that one should use the minimum dose able to effectively inhibit bud and shoot formation.

\section{Conclusion}

The organogenesis response of the strawberry (Fragaria $x$ ananassa Duch L.) in vitro is known to vary with the cultivar, explant type and concentration of plant growth regulators in the regeneration medium. In the present study with the 'Camino Real' and 'Festival' cultivars we observed organogenesis specific to the cultivar and type of explant. In the case of both cultivars, although petiole explants are typically seen in strawberry organogenesis, these proved unable to regenerate normal shoots; thus, under these conditions, we recommend only leaf explants. For the ideal 'Camino Real' regeneration medium we recommend $2.0 \mathrm{mg} \mathrm{L}^{-1} \mathrm{TDZ}+0.1 \mathrm{mg} \mathrm{L}^{-1}$ IBA; on the other hand, for 'Festival' regeneration medium we recommend $2.5 \mathrm{mg} \mathrm{L}^{-1} \mathrm{TDZ}+0.1 \mathrm{mg}$ $\mathrm{L}^{-1}$ IBA. With regard to kanamycin sensibility, although the usual recommendation is between 25 and $50 \mathrm{mg} \mathrm{L}^{-1}$ of kanamycin, we observed complete organogenesis inhibition with a smaller dose. For both cultivars we observed minimal differences with regard to the effects of kanamycin and recommend the addition of $10 \mathrm{mg} \mathrm{L}^{-1}$ of kanamycin to the regeneration medium for complete untransformed shoot inhibition.

\section{Acknowledgment}

The authors would like to thank CAPES for financial support.

\section{References}

ABDAL-AZIZ, S. A.; PLIEGO-ALFARO, F.; QUESADA, M. A.; MERCADO, J. A. Evidence of frequent integration of Non-T-DNA vector backbone sequences in transgenic strawberry plant. Journal of Bioscience and Bioengineering, Osaka, v. 101, n. 6, p. 508-510, 2006.

BAPAT, V. A.; TRIVEDI, P. K.; GHOSH, A.; SANE, V. A.; GANAPATHI, T. R.; NATH, P. Ripening of fleshy fruit: Molecular insight and the role of ethylene. Biotechnology Advances, New York, v. 28, n. 1, p. 94107, 2010.

BISWAS, M. K.; ROY, U. K.; ISLAM, R.; HOSSAIN, M. Callus culture from leaf blade, nodal, and runner segments of three strawberry (Fragaria sp. ) clones. Turk Journal Biology, Ankara, v. 34, n. 1, p. 75-80, 2010.

CARVALHO, D. C.; SILVA, A. L. L.; TANNO, G. N.; PURCINO, M.; BIASI, L. A. Organogenesis from leaf segments and internodes of grapevine cv. Merlot, Ciência e Agrotecnologia, Lavras, v. 35, n. 1, p. 108-114, 2011.

DEBNATH, S.; TEIXEIRA DA SILVA, J. A. Strawberry culture in vitro: applications in genetic transformation and biotechnology. Fruit, Vegetable and Cereal Science and Biotechnology, Kagawa, v. 1, n. 1, p. 1-12, 2007.

GASPAR, T. H.; KEVERS, C.; FAIVRE-RAMPANT, O.; CRE' VECOEUR, M.; PENEL, C. L.; GREPPIN, H.; DOMMES, J. Changing concepts in plant hormone action. In Vitro Cellular \& Developmental Biology Plant, Columbia, v. 39, n. 2, p. 85-106, 2003.

HADDADI, F.; AZIZ, M. A.; SALEH, G.; RASHID, A. A.; KAMALADINI, H. Micropropagation of Strawberry cv. Camarosa: Prolific Shoot Regeneration from In Vitro Shoot Tips Using Thidiazuron with N6-benzylaminopurine. Hort Science, Kent, v. 45, n. 3, p. 453-456, 2010.

HUETTEMAN, C. A.; PREECE, J. E. Thidiazuron: a potent cytokinin for wood plant tissue culture. Plant Cell, Tissue and Organ Culture, Dordrecht, v. 33, n. 2, p. 105$119,1993$.

HUSAINI, A. M. Pre- and post-agroinfection strategies for efficient leaf disk transformation and regeneration of transgenic strawberry plants. Plant Cell Reports, Berlin, v. 29, n. 1, p. 97-110, 2010. 
HUSAINI，A. M.; MERCADO, J. A.; TEIXEIRA DA SILVA, J.; SCHAART, J. G. Review of factors affecting organogenesis, somatic embryogenesis and Agrobacterium tumefaciens- mediated transformation of strawberry. Genes, Genomes and Genomics, Bethesda, v. 5, 1-11, 2011. Special Issue 1.

JIMÉNEZ-BERMÚDEZ, S.; REDONDO-NEVADO, J.; MUÑOZ-BLANCO, J.; CABALLERO, J. L.; LÓPEZARANDA, J. M.; VALPUESTA, V.; PLIEGO-ALFARO, F.; QUESADA, M. A.; MERCADO, J. A. Manipulation of strawberry fruit softening by antisense expression of pectate lyase gene. Plant Physiology, Waterbury, v. 128, n. 2, p. 751-759, 2002.

KARAMI, O.; ESNA-ASHARI, M.; KARIMI, K. G.; AGHAVAISI, B. Agrobacterium-mediated genetic transformation of plants: the role of host. Biologia Plantarum, Praga, v. 53, n. 2, p. 201-212, 2009.

LANDI, L.; MEZZETTI, B. TDZ, auxin and cultivar effects on leaf organogenesis in Fragaria. Plant Cell Reports, Berlin, v. 25, n. 4, p. 281-288, 2006.

MARCELLINO, L. H.; ROMANO, E.; GANDER, E. S. identificação de plantas transgênicas. In: TORRES, A. C.; DUSI, A. N.; SANTOS, M. D. M. Transformação genética de plantas via Agrobacterium: teoria e prática. Brasília: Embrapa Hortaliças, 2007. cap. 3, p. 61-80.

MOTTE, H.; VEREECKE, D.; GEELEN, D.; WERBROUCK, S. The molecular path to in vitro shoot regeneration. Biotechnology Advances, New York, v. 32, n. 1, p. 107-121, 2013.

MURASHIGE, T.; SKOOG, F. A Revised medium for rapid growth and bio-assays with tobacco tissue cultures. Physiologia Plantarum, Copenhagen, v. 15, n. 3, p. 437496, 1962.

MURTHY, B. N. S.; MURCH, S. J.; SAXENA, P. K. Thidiazuron: a potent regulator of in vitro plant morphogenesis. In Vitro Cellular \& Developmental Biology - Plant, Wallingford, v. 34, n. 4, p. 267-275, 1998.

MURTIL, R. H.; DEBNATH, S. C.; YEOUNG, Y. R. Effect of high concentration of thidiazuron (TDZ) combined with 1H-indole-3-butanoic acid (IBA) on Albion strawberry (Fragaria $\times$ ananassa) cultivar plantlets induction. African Journal of Biotechnology, Kenya, v. 11, n. 81, p. 14696-14702, 2012.

PALOMER, X.; LLOP-TOUS, I.; VENDRELL, M.; KRENS, F. A.; SCHAART, J. G.; BOONE, M. J.; VALK, H. V. D.; SALENTIJN, E. M. J. Antisense downregulation of strawberry endo- $\beta$ - $(1,4)$-glucanase genes does not prevent fruit softening during ripening. Plant Science, Ottawa, v. 171, n. 5, p. 640-646, 2006.
PANTAZIS, C. J.; FISK, S.; MILLS, K.; FLINN, B. S.; SHULAEV, V.; VEILLEUX, R. E.; DAN, Y. Development of an efficient transformation method by Agrobacterium tumefaciens and high throughput spray assay to identify transgenic plants for woodland strawberry (Fragaria vesca) using nptII selection. Plant Cell Report, Berlin, v. 32, n. 3, p. 329-337, 2013.

QIN, Y. H.; TEIXEIRA DA SILVA, J. A.; BI, J. H.; ZHANG, S. L.; HU, G. B. Response of in vitro strawberry to antibiotics. Journal of Plant Growth Regulation, New York, v. 65, n. 1, p. 183-193, 2011.

QIN, Y.; TEIXEIRA DA SILVA, J. A.; ZHANG, L.; ZHANG, S. Transgenic strawberry: state of the art for improved traits. Biotechnoogyl Advances, New York, v. 26, n. 3, p. 219-232, 2008.

QUESADA, M. A.; BLANCO-PORTALES, R.; POSÉ, S.; GARCÍA-GAGO, J. A.; JIMÉNEZ-BERMÚDEZ, S.; MUÑOZ-SERRANO, A.; CABALLERO, J. L.; PLIEGOALFARO, F.; MERCADO, J. A.; MUÑOZ-BLANCO, J. Antisense down-regulation of the FaPG1 gene reveals an unexpected central role for polygalacturonase in strawberry fruit softening. Plant Physiology, Waterbury, v. 150, n. 2, p. 1022-1032, 2009.

SILVA, A. L. L.; OLIVEIRA, Y.; COSTA, J. L.; MASETTO, E.; MUDRY, C. S.; LEMUS ERASMO, E. A.; SCHEIDT, G. N. Shoot tip and cotyledon explants of Eucalyptus saligna $\mathrm{Sm}$. cultivated on different kanamycin levels. Journal of Biotechnology and Biodiversity, Gurupi, v. 1, n. 1, p. 1-5, 2010.

SILVA, F. de A. S. E.; AZEVEDO, C. A. V. de. Principal components analysis in the software assistat-statistical attendance. In: WORLD CONGRESS ON COMPUTERS IN AGRICUlTURE, 7., 2009, Reno. Proceedings... Reno: American Society of Agricultural and Biological Engineers, 2009. p. 22-24.

SONG, C.; MA, J.; TANG, X.; ZHANG, Z.; ZHOU, P.; HOU, Z. Cloning of strawberry FaEtr2 gene and its plant expression vector construction for antisense RNA. Frontiers of Agriculture in China, Beijing, v. 3, n. 1, p. 55-59, 2009.

SUN, J. H.; LUO, J. J.; TIAN, L.; LI, C. L.; XING, Y.; SHEN, Y. Y. New evidence for the role of ethylene in strawberry fruit ripening. Journal of Plant Growth Regulation, New York, v. 32, n. 3, p. 461-470, 2013.

TRAINOTTI, L.; PAVANELLO, A.; CASADORO, G. Different ethylene receptors show an increased expression during the ripening of strawberries: does such an increment imply a role for ethylene in the ripening of these non-climacteric fruits. Journal of Experimental Botany, Oxford, v. 56, n. 418, p. 2037-2046, 2005. 
VILLARREAL， N. M.; BUSTAMANTE, C. A.; CIVELLO, P. M.; MARTÍNEZ, G. A. Effect of ethylene and 1-MCP treatments on strawberry fruit ripening. Journal of the Science of Food and Agriculture, London, v. 90, n. 4, p. 683-689, 2010.
ZAKARIA, H.; HUSSEIN, G. M.; ABDEL-HADI, A. A.; ABDALLAH, N. A. Improved regeneration and transformation protocols for three strawberry cultivars. GM Crops and Food: Biotechnology in Agriculture and the Food Chain, Dorchester, v. 5, n. 1, p. 4-3, 2013. 